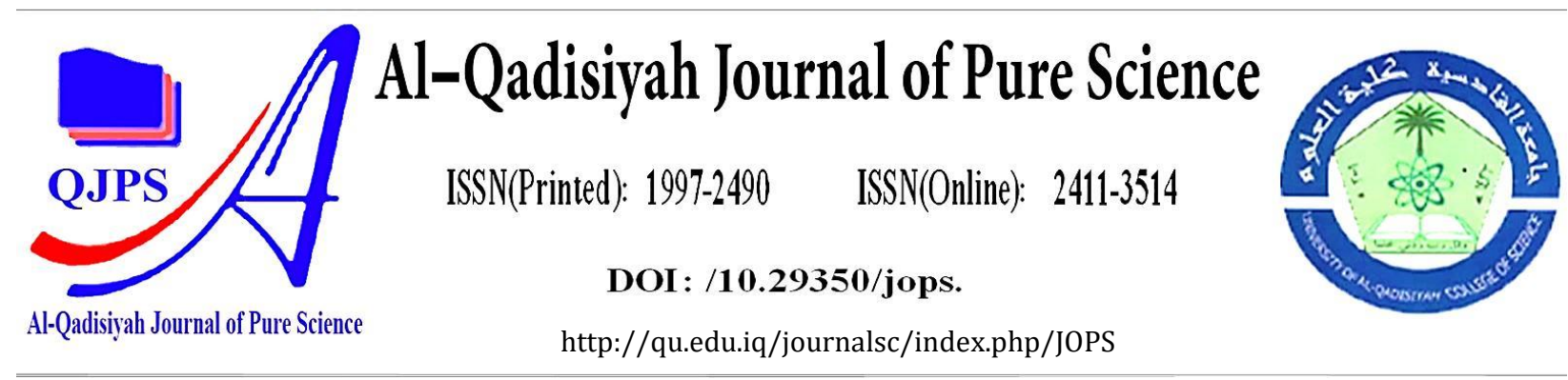

\title{
Traditional Medicinal plants Used for the Treatment of Cancer in Mubi, Adamawa State, Nigeria
}

\section{Authors Names \\ a. Isah Labaran \\ b. Mahmoud Dogara \\ Abdulrahman \\ c. Saber W. Hamad \\ d. Abubakar Abdullahi Lema \\ e. Bello Hassan Jakada}

\section{Article History}

Received on: $1 / 7 / 2021$

Revised on: 30/7/2021

Accepted on:5/8/2021

\section{Keywords:}

Medicinal plants ,Used Value Fidelity level, Relative

Frequency Citation

DOI: https://doi.org/10.29350/

jops.2021.26. 4.1423

\begin{abstract}
Medicinal plants have aided in the establishment and expansion of the modern healthcare system. Plants with medicinal potential are still the only way forward, as their acceptance and recognition spread over the globe. Ethnobotany is an interdisciplinary field that studies how people use plants in their daily lives. Nigeria accounted for roughly $20 \%$ of Africa's population and slightly more than half of West Africa's projected 681,000 new cancer cases in 2008, accounting for roughly $20 \%$ of the continent's population and slightly more than half of West Africa's. For pharmaceutical exploration and conservation, it is important to document the use of medicinal plants in a specific region across time. The study's goal was to find out which plants were used to treat Cancer in Mubi, Northern eastern part of Nigeria. An open ended interview was employed with no sampling size selection. Used Value (UV), Fidelity level (FL) and Relative frequency of citation (RFC) were used to determine the most important and effective plants used for treatment of cancer. Ten plants were documented with Neolamarckia cadamba has $0.9,1$ and $100 \%$ of UV, RFC and FL, respectively. The study will serve as a foundation for subsequent research into developing natural medicine or modern medications to prevent the extinction of the species.
\end{abstract}

\section{Introduction}

Cancer is a condition in which cells divide uncontrollably and abnormally. In 2012, roughly 14 million new cancer cases and 8.2 million cancer-related deaths were reported worldwide [1]. Nigeria produced $15 \%$ of Africa's projected 681,000 new cancer cases in 2008, accounting for around $20 \%$ of the continent's population and slightly more than half of West Africa's [2]. In Nigeria, 100,000 new cancer cases are detected each year, with a high case fatality rate [3]. The six most frequent in Nigeria, in descending order of frequency, are breast, cervix, prostate, colorectal, liver, and non-Hodgkins lymphoma [4]. Traditional medical practitioners (TMPs) are reported to treat cancer, as well as many other diseases, in Nigeria and around the world [5]. Cancer is the second most fatal disease, after only

a Department of Sciences Laboratory Technology, School of Science, Federal polytechnic Mubi, Adamawa state, Nigeria

b Department of Biology, Faculty of Education, Tishk International University, Erbil, Kurdistan Region, Iraq EMAIL:

abdulrahman.mahmud@tiu.edu.iq

c Department of Field Crops Production, College of Agricultural Engineering Sciences, Salahaddin University-Erbil, Kurdistan

Region, Iraq

d Department of plant science and biotechnology faculty of bioresources and food industry university Sultan Zainal Abidin

Malaysia

e Genomics and Biotechnology Center, Haixia Institute of Science and Technology, Fujian Agriculture and Forestry University.

China. 
cardiovascular disease, and it is a serious public health concern around the world [5]. The global incidence of cancer and cancer-related mortality continues to rise, particularly in developing and underdeveloped countries. In regions of Africa, particularly Nigeria, the frequency of cancer and cancer-related fatalities is steadily growing, which may be due to a lack of cheap healthcare for early detection and treatment [6]. Breast cancer (32.29\%) and digestive system cancer (19.67\%) are the most often diagnosed cancers in Ilorin, Kwara state Nigeria [7]. Breast cancer $(38.1 \%)$ and prostate cancer $(12.8 \%)$ are the most often diagnosed cancers in female and male Lagos, Nigeria [7]. Plants have long been known for their therapeutic properties, and people all over the world have traditionally employed them to cure a variety of maladies [8]. From the dawn of time, man has been fascinated with the knowledge and application of traditional medicinal plants, which has been passed down from generation to generation [9]. People choose to use medicinal plants because of the high expense of modern medicine [9]. According to the World Health Organization (WHO), more than 70\% of the world's population relies on traditional medicinal herbs for health care [10]. WHO (2009) reported more than $80 \%$ of the world's population used traditional herbal therapy to manage infectious diseases caused by their local environment [10]. Traditional medicinal herbs are increasingly being used in various forms all over the world [11]. Ethnobotany is crucial for learning how plants are used in different cultures [11]. Natural remedies derived from plants are now widely regarded as the safest and most effective means of combating infectious infections [12]. For biological exploration and conservation, it is critical to document the use of medicinal plants in a specific region over time [13]. Documentation of anticancer medicinal plants will aid in the development of new medications or herbal products. It has been demonstrated that if the enormous plant diversity of Nigeria is studied, it will give a promising novel anticancer chemical. As a result, using quantitative and qualitative data remains the sole way to obtain information from underutilized Nigerian plants in order to develop new anticancer medication. Through qualitative and quantitative ethnobotanical data, this study attempted to identify the key medicinal plants with anticancer potential in Mubi, Adamawa State, Northeast Nigeria.

\section{Materials and Methods}

\subsection{Study area}

Mubi is a town in Adamawa State, Nigeria's Northeast, in the Northern Senatorial District. It is located at $10^{\circ} 16^{\prime} \mathrm{N}, 13^{\circ} 16^{\prime} \mathrm{E}$ latitude and longitude (Figure 1). Mundang (Godo-godo), Fulani, Gude Nzanyi, Hausa, Fali, Higgi and Marghi are the largest inhabitant towns [9]. Farmers, fishermen, and businesspeople made up the majority of the population. Two distinct weather seasons, rainy and dry, characterize the climatic state [9]. 


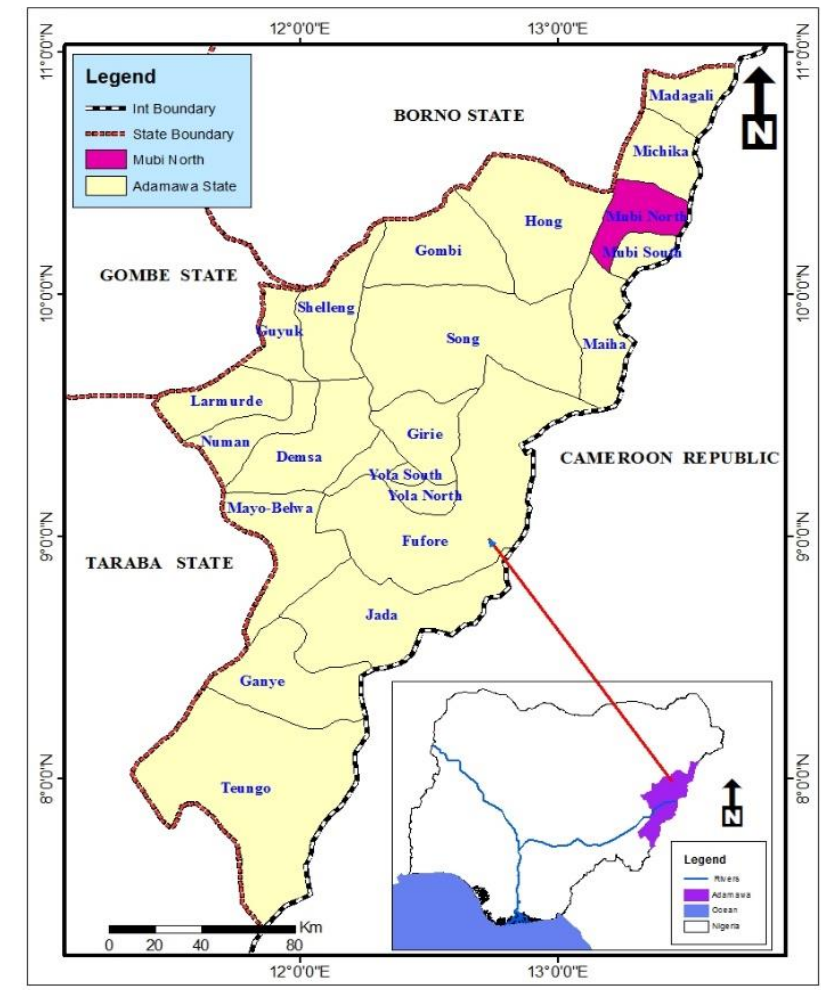

Figure 1: Map of the Study Area Identifying the Sampling Locations

\subsection{Sampling and Interview Sessions}

Expert sampling and non-random probability were used. No sampling size needed. A semi structured questionnaire was used to collect data from traditional medicine practitioners [9, 10]. Before being used in the study, the questionnaire was pre-tested and validated by three professional botanists. There was no prejudice in the selection of informants. Only traditional herbalist over the age of 45 were asked to participate in the study [10]. There was no prior arrangement with the informants. Informants, on the other hand, were briefed on why the studies were necessary prior to the interview. The informant desires to cooperate voluntarily.

\subsection{Plant Collection, Taxonomic Identification and Herbarium Deposition}

For the therapeutic plants collected from home gardens and natural environments, herbarium specimens were made. The plants were identified in the field by a botanist, validated in the Agricultural Department of the Federal Polytechnic Mubi in Adamawa State, Nigeria, and eventually put in the school herbarium. Voucher number were assigned (Table 2). 


\subsection{Data Analysis}

For the ethnobotanical data collected, a basic descriptive analysis was used to establish the percentages and frequencies, which were then tallied based on the following information $[9,10]$ :

I. Information about the informants' socio-demographics.

II. Taxonomic profile of the plants, preparation method, administration method, plant parts used, and growth form.

III. The perspectives of the informants on the use of traditional knowledge in the treatment of cancer

IV. The following indexes were used to calculate quantitative data:

a. RFC (Relative Frequency Citation)

The above characteristic was utilized to determine the plant's relative popularity within the community. $\mathrm{RFC}=\mathrm{Fc} / \mathrm{N}$, where $\mathrm{Fc}$ is the number of informants who mentioned a certain plant species and $\mathrm{N}$ denotes the total number of informants interviewed.

b. UV (Used Value)

In other to determine the relative importance of a plant the following equation was used : $\mathrm{UV}=\sum \mathrm{Ui} / \mathrm{N}$. Where, $\mathrm{Ui}=$ is the total number of uses mentioned by each respondent and $\mathrm{N}$ is the total number of informants interviewed [9].

\section{c. FL (Fidelity Level)}

Using the equation below, this parameter was used to determine the ability of a given plant species to cure a specific ailments.: $\mathrm{FL}=\mathrm{Ns} / \mathrm{N} \times 100$. Where $\mathrm{Ns}=$ indicates the total number of people who said they used a specific plant species to treat a specific ailment and $\mathrm{N}=$ is the total number of informants who cited the plants species during interviewed [9].

\section{Results and Discussion}

\subsection{Demographics profile of the respondents}

An ethnobotanical study conducted in Nigeria's northern eastern region focuses on ethno phyto therapeutic cancer medicinal plants. Modern and traditional medicine relied on medicinal plants. Despite significant advances in synthetic organic medicinal products during the twentieth century, over $25 \%$ of prescribed medicines in the developed countries are made directly or indirectly from plants [9, 10]. Plants have been used as sources of treatments for a range of ailments since ancient times, and people from many continents, particularly Africa still depend on it [9]. In Nigeria more than $70 \%$ of the rural population relies on traditional herbalist to meet their primary health care $[9,14]$. A total of thirty two traditional herbalist were interviewed but only eighteen are considered in the following study. Because the eighteen are found to be very knowledge on the treatment of cancer. The sampling method adopted in the study, consider only traditional herbalist with the versatile knowledge of using medicinal plants to treat cancer [10]. The following sampling method was adopted in many traditional 
medicinal research all over the world $[9,10]$. The following study found predominance of men against women (Table 2). The findings could be linked to the fact that women in Nigerian communities are solely responsible for household activities, and majority of them regard being full-time housewives to be their primary occupation. As a result, they are unable to learn more about traditional therapeutic herbs. The present is in conformity with the previous ethnobotanical research carried out in Nigeria and other part of the world [9, 15-17]. The elderly were discovered to be the community's custodians of traditional medicinal knowledge. (Table 1 and figure 2). The pre-test of the study carried out found the age group bellow 40 years are less knowledgeable or has no knowledge of the traditional medicinal plants in the community. This is due to the present generation are more attached to the urbanization. The study found possible loss of traditional medicinal knowledge in the northern eastern part of Nigeria due lack of interest of the younger generation and the demise of the old people. Similar situation was reported in at some African countries and other part of the world [18, 19]. More 50\% of the interviewed informants do not attend basic education only $27.8 \%$ attended (Table 1). Despite basic education is compulsory in Nigeria. But all the informants have attended and still obtaining religious knowledge. 33.3 of the interviewed informants has more than 30 years of traditional medicinal practice (Table 2 and figure 3 ).

Table 1: Demographic Profile of the Informants

\begin{tabular}{|l|l|l|}
\hline Gender & Frequency & Percentage \\
\hline Male & 13 & 72.2 \\
\hline Female & 5 & 27.8 \\
\hline Age & & \\
\hline $40-50$ & 3 & 16.7 \\
\hline $51-60$ & 3 & 16.7 \\
\hline $61-70$ & 8 & 44.4 \\
$71->$ & 4 & 22.2 \\
\hline Education & & \\
\hline Basic education & 5 & 27.8 \\
\hline Post basic education & 2 & 11.1 \\
\hline Tertiary & 1 & 5.6 \\
\hline None & 10 & 55.6 \\
\hline
\end{tabular}

\subsection{Taxonomic Domestication of Medicinal plants Used for the treatment of Cancer}

Detailed information about traditional medicinal plants used to treat cancer by the people of Mubi, Adamawa State, Nigeria (Table 2). The scientific names, family names, common names, vernacular names, portion used, method of preparation, and route of administration for the plants documented 
during the study period are listed in Table 2. Many plants were reported during the in depth interview but only ten were consider most effective medicinal plants in the community to treat cancer based on the quantitative indices. Only plants species with high UV, RFC and FL were reported (Table 3). The maximum value for UV and RFC is $1[9,10]$.

Table 2: Medicinal Plants Utilisation and Domestication Status for the treatment of Cancer in Mubi, Nigeria

\begin{tabular}{|c|c|c|c|c|c|c|c|c|c|}
\hline $\begin{array}{l}\mathrm{S} / \\
\mathrm{N}\end{array}$ & $\begin{array}{l}\text { Species } \\
\text { name }\end{array}$ & Family name & $\begin{array}{l}\text { Common } \\
\text { Name }\end{array}$ & $\begin{array}{l}\text { Local } \\
\text { Name }\end{array}$ & $\begin{array}{l}\text { Part } \\
\text { of the } \\
\text { plant } \\
\text { Used }\end{array}$ & $\begin{array}{l}\text { Method } \\
\text { of } \\
\text { preparatio } \\
\text { n }\end{array}$ & $\begin{array}{l}\text { Method of } \\
\text { administrati } \\
\text { on }\end{array}$ & $\begin{array}{l}\text { Domesticati } \\
\text { on Status }\end{array}$ & $\begin{array}{l}\text { Vouch } \\
\text { er No }\end{array}$ \\
\hline 1 & $\begin{array}{l}\text { Adansonia } \\
\text { digitata } \\
\text { L. }\end{array}$ & Malvaceae & $\begin{array}{l}\text { African } \\
\text { baobab }\end{array}$ & Kuka & $\begin{array}{l}\text { Leave } \\
\mathrm{s}\end{array}$ & Decoction & Oral & Wild & IL 360 \\
\hline 2 & $\begin{array}{l}\text { Boswellia } \\
\text { dalzielii } \\
\text { Hutch. }\end{array}$ & Burseraceae & $\begin{array}{l}\text { Frankincen } \\
\text { se tree }\end{array}$ & Harrabi & Bark & Decoction & Oral & Wild & IL 358 \\
\hline 3 & $\begin{array}{l}\text { Commiphor } \\
\text { a africana } \\
\text { (A.Rich.) } \\
\text { Endl. }\end{array}$ & Burseraceae & $\begin{array}{l}\text { African } \\
\text { myrrh }\end{array}$ & Dashi & $\begin{array}{l}\text { Leave } \\
\mathrm{s}\end{array}$ & Decoction & Oral & Wild & IL 366 \\
\hline 4 & $\begin{array}{l}\text { Detarium } \\
\text { microcarpu } \\
m \text { Guill. \& } \\
\text { Perr }\end{array}$ & Fabacea & sweet detar & Taura & $\begin{array}{l}\text { Leave } \\
\text { s, } \\
\text { Bark, } \\
\text { Root }\end{array}$ & $\begin{array}{l}\text { Decoction } \\
\text {, Infusion }\end{array}$ & Oral & Wild & IL 357 \\
\hline 5 & $\begin{array}{l}\text { Dialium } \\
\text { guineense } \\
\text { Willd. }\end{array}$ & Fabaceae & $\begin{array}{l}\text { Velvet } \\
\text { tamarind }\end{array}$ & $\begin{array}{l}\text { Tsamiy } \\
\text { an biri }\end{array}$ & $\begin{array}{l}\text { Leave } \\
\mathrm{s}\end{array}$ & $\begin{array}{l}\text { Decoction } \\
\text { mercerati } \\
\text { on }\end{array}$ & Oral & Wild & IL 361 \\
\hline 6 & $\begin{array}{l}\text { Guiera } \\
\text { senegalensis } \\
\text { J.F. Gmel }\end{array}$ & $\begin{array}{l}\text { Combretacea } \\
\text { e }\end{array}$ & Sabara & Sabara & $\begin{array}{l}\text { Leave } \\
\mathrm{s}\end{array}$ & Decoction & $\begin{array}{l}\text { Oral, } \\
\text { Dermal }\end{array}$ & Wild & IL 362 \\
\hline 7 & $\begin{array}{l}\text { Leptadenia } \\
\text { hastata (Pers } \\
\text {.) Decne }\end{array}$ & $\begin{array}{l}\text { Asclepiadace } \\
\text { ae }\end{array}$ & Anvara & Yadiya & $\begin{array}{l}\text { Leave } \\
\mathrm{s}\end{array}$ & Decoction & $\begin{array}{l}\text { Oral, } \\
\text { dermal }\end{array}$ & Wild & IL 363 \\
\hline 8 & $\begin{array}{l}\text { Mangifera } \\
\text { indica } \\
\mathrm{L}\end{array}$ & $\begin{array}{l}\text { Anacardiace } \\
\text { ae }\end{array}$ & Mango & $\begin{array}{l}\text { Mangor } \\
\text { o }\end{array}$ & $\begin{array}{l}\text { Leave } \\
\mathrm{s}\end{array}$ & Decoction & Oral & $\begin{array}{l}\text { Wild, } \\
\text { Cultivated }\end{array}$ & IL 365 \\
\hline 9 & $\begin{array}{l}\text { Neolamarcki } \\
\text { a cadamba } \\
\text { (Roxb.) Bos } \\
\text { ser }\end{array}$ & Rubiaceae & $\begin{array}{l}\text { Burflower } \\
\text { tree }\end{array}$ & Kadam & $\begin{array}{l}\text { Leave } \\
\mathrm{s}\end{array}$ & Decoction & Oral & Wild & IL 359 \\
\hline 10 & $\begin{array}{l}\text { Prosopis } \\
\text { africana } \\
\text { (Guill. \& } \\
\text { Perr.) Taub. }\end{array}$ & Fabaceae & Iron tree & Kiriya & $\begin{array}{l}\text { Leave } \\
\mathrm{s}\end{array}$ & Decoction & Oral & Wild & IL 364 \\
\hline
\end{tabular}


Table 3: Quantitative Evaluation of the Documented Medicinal Plants

\begin{tabular}{|l|l|l|l|l|}
\hline S/N & Species Name & UV & RFC & FL\% \\
\hline 1 & $\begin{array}{l}\text { Adansonia digitata } \\
\text { L. }\end{array}$ & 0.8 & 1 & 94 \\
\hline 2 & $\begin{array}{l}\text { Boswellia dalzielii } \\
\text { Hutch. }\end{array}$ & 0.7 & 1 & 88 \\
\hline 3 & $\begin{array}{l}\text { Commiphora africana } \\
\text { (A.Rich.) Endl. }\end{array}$ & 0.8 & 1 & 88 \\
\hline 4 & Detarium microcarpum Guill. \& Perr & 0.8 & 1 & 94 \\
\hline 5 & Dialium guineense Willd. & 0.7 & 1 & 88 \\
\hline 6 & $\begin{array}{l}\text { Guiera senegalensis } \\
\text { J.F. Gmel }\end{array}$ & 0.9 & 1 & 94 \\
\hline 7 & Leptadenia hastata (Pers.) Decne & 0.8 & 1 & 88 \\
\hline 8 & $\begin{array}{l}\text { Mangifera indica } \\
\text { L }\end{array}$ & 0.7 & 1 & 100 \\
\hline 9 & $\begin{array}{l}\text { Neolamarckia cadamba } \\
\text { (Roxb.) Bosser }\end{array}$ & 0.9 & 1 & 100 \\
\hline 10 & Prosopis africana (Guill. \& Perr.) Taub. & 0.9 & 1 & 94 \\
\hline
\end{tabular}

Note: $\mathbf{S} / \mathbf{N}=$ Serial Number

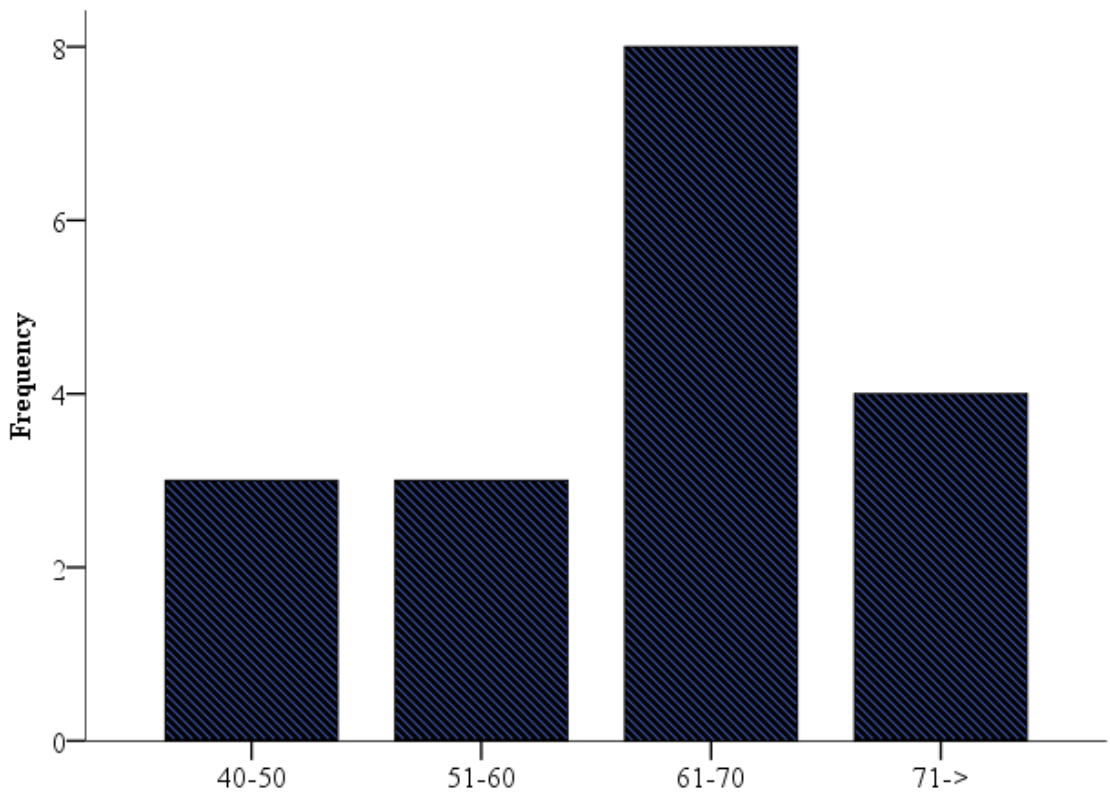

Figure 2: Age distribution of the informants in Mubi, Nigeria 


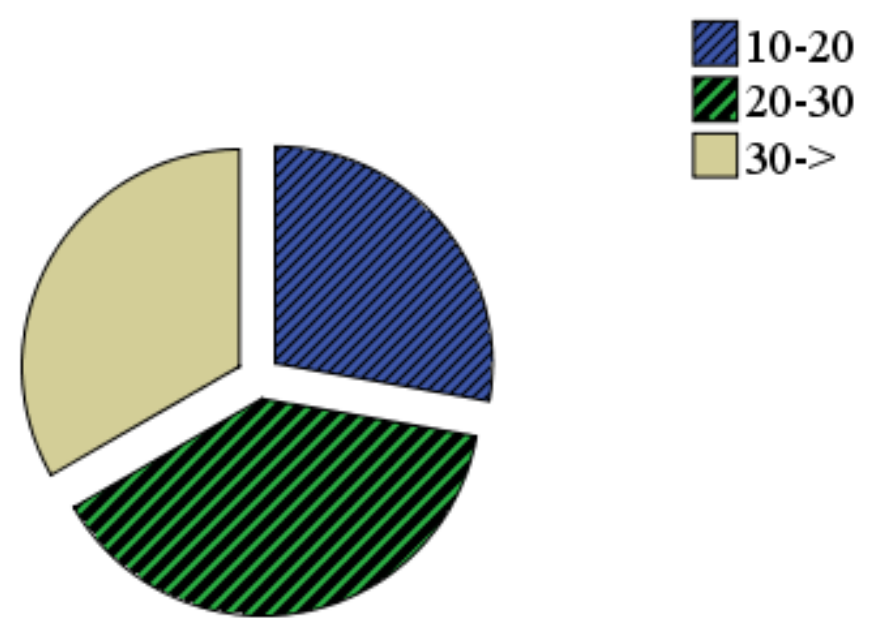

Figure 3: Experience of the informants in Traditional medicinal practice in Mubi, Nigeria

\subsection{Parts of the plants Used, Method of Preparation, Dosage, Administration and Domestication status}

Excessive use of plant parts has the potential to lead to the extinction of medicinal plants in Nigeria [15]. Leaves were found to be the most utilised plants parts (57.1) followed by bark (28.6\%) and root (14.3\%) (Figure 4) This study discovered that the leaves are frequently used, most likely because secondary metabolites are predominantly produced in the leaves, where photosynthesis occurs, and then transferred to other sections of the plant. It could also be because the leaves are easier to harvest than other parts of the plant, such as the root and bark. The study did not correspond on the ethno botanical studies carried out in other part of Nigeria [16, 20]. They reported root as the most utilised part of medicinal plants and this caused a serious challenge to the biodiversity. Decoction is most utilised form of preparation of the medicinal plants parts collected for the management of cancer $(57.1 \%)$ while infusion (33.3\%) and maceration (9.5\%) all with aid of water (Figure 5). Decoction utilisation is as a results of the hot water extraction, which enable extractions of more substances from plant pars, including the elements that give the plant its therapeutic potential. Doction have mostly reported as the most prepared method $[15,20]$. 


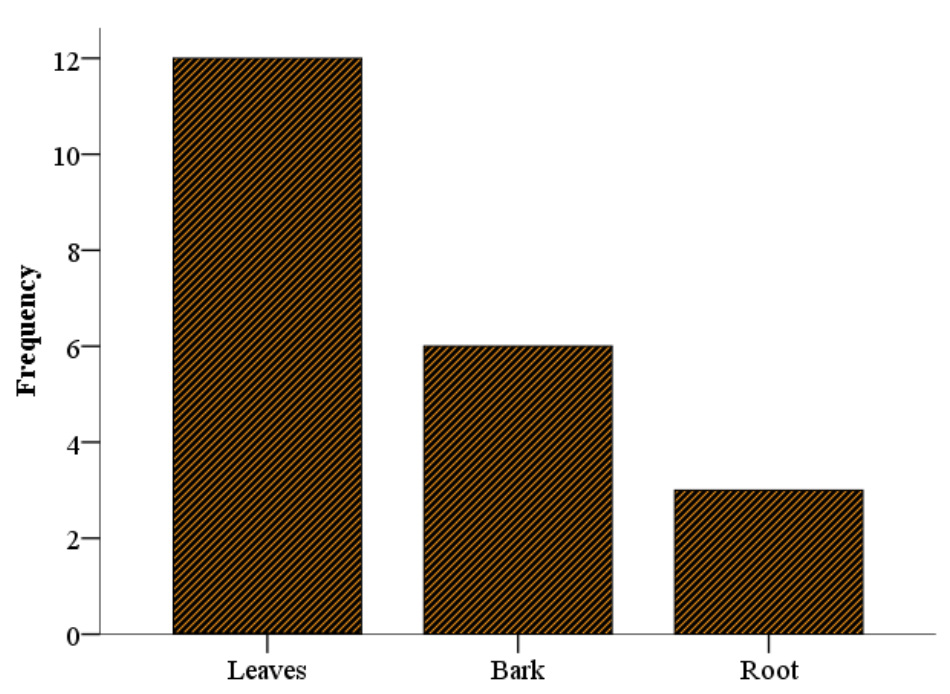

Figure 4: Parts of the plant Utilised in Traditional medicinal practice in Mubi, Nigeria

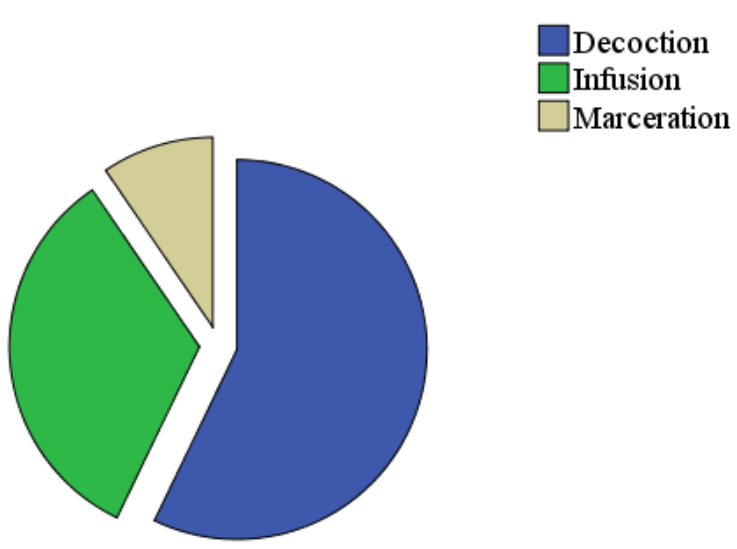

Figure 5: Method of Preparation of Traditional Medicinal Plants in Mubi, Nigeria

Although some traditional herbalists have reported that the factor of age and the severity of the disease, the discrepancy or variation may be as a result of learned traditional knowledge from the elders or experience gained from the community, there is no specific dosage recommended for patients to take. Despite the fact that it was certified safe for comsumption by the traditional herbalist, this created a serious dilemma; it may still be hazardous because it had not been properly validated. The informants reported using medicinal plant parts largely in dried form, however this is due to the fact that the plants are wild, and they are sometimes frightened that the plant will dry entirely after the rainy season, so they harvest in excess to save for future use. The effectiveness of the oral (71.4\%) and dermal $(28.6 \%)$ methods was reported by the informants, respectively (Figure 6). The extract's synergistic action on the targeted tissue was the source of its effectiveness $[9,15]$. 
Oral

Dermal

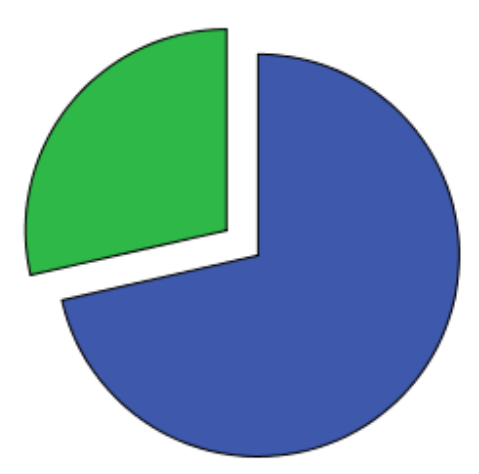

Figure 6: Method of Administration of Traditional Medicinal Plants in Mubi, Nigeria

\subsection{Medicinal Plants toxicity}

The ethnomedicinal data collected from the respondents provide light on the toxicity of medicinal herbs used to cure cancer. According to their experience with traditional plant knowledge, using plants to treat diseases has no negative side effects. However, some people believe it can be hazardous if consumed in large quantities or if the wrong prescription is taken. The findings are in line with those of many other traditional medicinal plant studies $[9,21]$. Before certifying therapeutic plants to be nontoxic, proper scientific validation must be completed.

\section{Conclusion}

Mubi, Adamawa state, Nigeria's north eastern region, is well-versed in their culture's use of traditional medicinal plants for cancer therapy. Despite the younger generation's interest on the traditional medicinal plants utilisation, the study found that only the elderly are the custodians of knowledge. As a result, the study suggests conducting a comprehensive ethnobotanical examination of the community on other ailments before the demise of the elderly. The findings will serve as a foundation for subsequent research into developing natural medicine or modern medications to prevent the extinction of the species.

\section{Acknowledgements}

The author wishes to acknowledge the respondents for sharing their valuable knowledge for the development of our great Nation.

\section{Conflict of interest}

Author do not have any conflict of interests to declare. The author alone are responsible for the content of the paper. 


\section{References:}

[1] Bowen JP, Andrew Z H. Editorial (Thematic Issue: Advances in Drug Discovery for the Treatment of Cancer: Many Approaches, One Goal). Current topics in medicinal chemistry, 2016; 16(13): 1411-1412

[2] Azubuike SO, Muirhead C, Hayes L, McNally R. Rising global burden of breast cancer: the case of sub-Saharan Africa (with emphasis on Nigeria) and implications for regional development: a review. World journal of surgical oncology, 2018; 16(1): 1-13.

[3] Fapohunda A, Fakolade A, Omiye J, Afolaranmi O, Arowojolu O, Oyebamiji T, Mutiu J. Cancer presentation patterns in Lagos, Nigeria: Experience from a private cancer center. Journal of public health in Africa, 2020; 11(2). 1-7.

[4] AO P, Omodele F, Oludara M, NA I, AI I, SBL M. Prevalence and pattern of cancers among adults attending a tertiary health institution in Lagos, Nigeria. Journal of Dental and Medical Sciences, 2013; 6(3): 68-73.

[5] Segun PA, Ogbole OO, Ajaiyeoba EO. Medicinal plants used in the management of cancer among the Ijebus of Southwestern Nigeria. Journal of herbal medicine, 2018; 14. 68-75.

[6] Cheng TYD, Cramb SM, Baade PD, Youlden DR, Nwogu C, Reid ME. The international epidemiology of lung cancer: latest trends, disparities, and tumor characteristics. Journal of Thoracic Oncology, 2016; 11(10): 1653-1671.

[7] Abubakar IB, Ukwuani-Kwaja AN, Olayiwola FS, Malami I, Muhammad A, Ahmed SJ, Falana MB. An inventory of medicinal plants used for treatment of cancer in Kwara and Lagos state, Nigeria. European Journal of Integrative Medicine, 2020; 34: 101-116.

[8] Li FS, Weng JK. Demystifying traditional herbal medicine with modern approach. Nature plants, $2017 ; 3$ (8): 1-7.

[9] Mahmoud AD, Labaran I, Yunusa A. Ethnobotany of medicinal plants with antimalarial potential in Northern Nigeria. Ethnobotany Research and Applications, 2020; 19: 1-8.

[10] Awang NA, Ali AM, Abdulrahman MD, Mat N. Edible bitter mushroom from Besut, Malaysia. Journal of Agrobiotechnology, 2018; 9(2): 70-79.

[11] Payyappallimana U. Role of traditional medicine in primary health care: An overview of perspectives and challenging. Unnikrishnan Payyappallimana, 2010; 1-22.

[12] Abd Kadir SL, Yaakob H, Zulkifli RM. Potential anti-dengue medicinal plants: a review. Journal of natural medicines, 2013; 67(4): 677-689.

[13] Kala CP, Dhyani PP, Sajwan BS. Developing the medicinal plants sector in northern India: challenges and opportunities. Journal of Ethnobiology and Ethnomedicine, 2006; 2(1): 1-15.

[14] Sen S, Chakraborty R, Revival A. modernization and integration of Indian traditional herbal medicine in clinical practice: Importance, challenges and future. Journal of traditional and complementary medicine, 2017. 7(2): $234-244$.

[15] Kankara SS, Ibrahim MH, Mustafa M, Go R. Ethnobotanical survey of medicinal plants used for traditional maternal healthcare in Katsina state, Nigeria. South African journal of botany, 2015; 97: 165-175.

[16] Kankara SS, Isah AB, Bello A, Ahmed A, Lawal U. Medicinal plants used for the management of hepatic ailments in Katsina State, Nigeria. Journal of Medicinal Plants Research, 2018; 12(24): 375-386.

[17] Mahmoud AD, Fatihah HNN, Khandaker MM, Ali AM, Mat N. Ethnobotany of Syzygium polyanthum (Wight) Walp In Terengganu, Peninsular Malaysia. Journal Of Agrobiotechnology, 2020; 11(2): 39-47.

[18] Packer J, Brouwer N, Harrington D, Gaikwad J, Heron R, Elders YC, Jamie J. An ethnobotanical study of medicinal plants used by the Yaegl Aboriginal community in northern New South Wales, Australia. Journal of Ethnopharmacology, 2012; 139(1): 244-255.

[19] Njoroge GN, Kaibui IM, Njenga PK, Odhiambo PO. Utilisation of priority traditional medicinal plants and local people's knowledge on their conservation status in arid lands of Kenya (Mwingi District). Journal of ethnobiology and ethnomedicine, 2010; 6(1): 1-8.

[20] Muhammad S, Shinkafi M. Ethnobotanical survey of some medicinal important leafy vegetables in North Western Nigeria. Journal of Medicinal Plants Research, 2014; 8(1): 6-8.

[21] Abdulrahman MD, Ali AM, Fatihah H, Khandaker MM, Mat N. Traditional medicinal knowledge of Malays in Terengganu, Peninsular Malaysia. Malayan Nature Journal, 2018; 70(3): 349-364. 